\title{
PERJUANGAN TOKOH PEREMPUAN DALAM CERITA PENDEK “AIR" KARYA DJENAR MAESA AYU
}

\author{
Nuraini Asriningsih ${ }^{1}$, Turahmat ${ }^{2}$ \\ Universitas Islam Sultan Agung Semarang 1,2 \\ Posel: nurainiasriningsih@std.unissula.ac.id ; lintangsastra@unissula.ac.id
}

\begin{abstract}
This short "water" story by Djenar Maesa Ayu is the background of the life of a woman who struggled and worked hard to raise her child, without getting the responsibility of the prospective baby's father. The problem of this research is the struggle of female leaders. This study aims to describe the struggles of female leaders in the short story Air by Djenar Maesa Ayu. This study uses a feminist literary criticism approach. The method used is descriptive qualitative. The data source is Air's short story by Djenar Maesa Ayu. The technique used is the data validation technique. This research draws conclusions about the struggles of female leaders.
\end{abstract} Keywords: the struggle of female leaders; short stories.

Abstrak

Cerita pendek “air" karya Djenar Maesa Ayu ini belatar belakang kehidupan tokoh seorang perempuan yang berjuang dan bekerja keras demi membesarkan anaknya, tanpa mendapatkan pertanggung jawaban dari calon ayah si cabang bayi. Masalah penelitian ini mengenai perjuangan tokoh perempuan. Penelitian ini bertujuan untuk mendeskripsikan mengenai perjuangan tokoh perempuan dalam cerita pendek Air karya Djenar Maesa Ayu. Penelitian ini menggunakan pendekatan kritik sastra feminis. Metode yang digunakan adalah deskriptif berbentuk kualitatif. Sumber data adalah cerita pendek Air karya Djenar Maesa Ayu. Tekhnik yang digunakan adalah tekhnik validasi data. Penelitian ini menghasilkan kesimpulan mengenai perjuangan tokoh perempuan.

Kata kunci: perjuangan tokoh perempuan; cerita pendek.

\section{PENDAHULUAN}

Pembicaraan mengenai kesusasteraan tidak akan tercipta bila tidak ada sebuah karya sastra (Junus,1985:2). Sastra merupakan ungkapan pribadi manusia berupa perasaan, pengalaman, pemikiran, ide, gagasan, keyakinan, semangat, dalam suatu bentuk gambaran yang kongkret untuk membangkitkan pesona dengan bermacam ragam bahasa (Sumardjo dan Saini, 1994 : 3). Dari pernyataan tersebut mengandung makna bahwa manusia memanfaatkan karya sastra sebagai salah satu sarana untuk mencurahkan atau mengungkapkan perasaan, pengalaman, pemikiran ide, gagasan, keyakinan, dan semangat dalam bentuk karya sastra. Sehingga dapat disimpulkan bahwa karya sastra itu sangat bermanfaat bagi penulis maupun bagi pembacanya. Nilai-nilai yang terdapat dalam suatu karya sastra pada umumnya mencerminkan kehidupan sosial yang memberikan pengaruh kepada masyarakat. Oleh karena itu, peneliti sangat tertarik untuk mengkaji sebuah cerita pendek Air karya Djenar Maesa Ayu dari cerita pendek Kompas Pilihan 2005-2006. Jakarta, 13 Mei 2006, yang bertemakan perempuan dan perjuangan tokoh perempuan, penelitian ini menggunakan pendekatan penelitian kritik sastra feminis. Para pengkritik sastra feminis mempunyai tujuan penting dari kritik sastra feminis, yaitu bertujuan untuk membantu pembaca karya sastra dapat memahami, menafsirkan, mendeskripsikan, serta menilai karya-karya yang dibuat oleh penggarang (Djajanegara,2003:27). 
Geofe berpendapat feminisme yaitu teori mengenai persamaan antara laki-laki dan perempuan dalam bidang politik, sosial, dan ekonomi atau dalam bidang kegiatan yang terorganisasi dalam memperjuangkan hak-hak ataupun kepentingan bagi perempuan (Sugihastuti,2008:18). Gerakan feminisme muncul karena perbedaan makna yang tidak dipahami dengan baik oleh masyarakat anatara jenis kelamin dan gender (Darusalam, 221 223:2016) Teori feminisme selalu berkaitan dengan gender dan emansipasi. Feminisme berkaitan dengan gender sebagai wacana masyarakat yang membedakan sebuah hak dan kewajiban antara laki-laki dan perempuan berdasarkan dengan jenis kelamin. Munculnya istilah gender yaitu sebagai batasan-batasan yang sama dengan satu jenis kelamin pada setiap individu. Peran gender merupakan peran penting yang dibuat oleh masyarakat untuk kaum laki-laki maupun kaum perempuan. Gender merupakan sifat yang sudah melekat pada kaum laki-laki dan dan kaum perempuan (Fakih 2010:08). Ratna (2004 : 191) mengungkapkan bahwa pekerjaan kaum perempuan selalu dihubungkan dengan pekerjaan ringan, sedangkan pekerjaan kaum laki-laki dengan pekerjaan berat.

Penelitian ini berfokus tentang feminisme mengenai perjuangan tokoh perempuan dalam cerita pendek Air karya Djenar Maesa Ayu dari cerita pendek Kompas Pilihan 20052006. Jakarta, 13 Mei 2006. Tokoh perempuan mengalami sebuah ketidak adilan, kemudian tokoh perempuan melakukan melawan ketidak adilan untuk mensejahterakan hidupnya. Penelitian mengenai feminisme juga pernah diteliti oleh Indriyana Uli (Untan2011) menggunakan pendekatan kritik sastra feminis pada novel karya Langit Kresna Hariadi (sastra feminis) yang berjudul Harga Sebuah Martabat. Permasalahan yang diteleti mengenai 1) kedudukan perempuan dalam pendidikan, karier, serta hukum. 2) Meneliti profeminis dan kontrafeminis pada novel. Penelitian tersebut menghasilkan kesimpulan kedudukan tokoh perempuan yaitu kedudukan pendidikan dan karier mendapatkan kedudukan yang sama dengan laki-laki, namun tidak dalam bidang hukum. Bentuk kontrafeminis berupa penganiayaan terhadap perempuan, sedangkan bentuk profeminis berupa menghargai perempuan. Ada pandangan bahwa pengkritik dan pembaca laki-laki belum mampu menilai karangan wanita dengan baik (Santosa,2009,47-56).

Menurut (Aminudin 2995:79) tokoh ialah pelaku yang mengalami peristiwa dalam sebuah cerita fiksi sehingga peristiwa tersebut dapat menjain sebuah cerita. Sedangkan menurut Jones (dalam Nugriyantoro, 2000:165), penokohan merupakan pelukisan gambaran yang nyata mengenai seseorang yang disajikan dalam bentuk sebuah cerita. Berdasarkan pengertian diatas, pengertian penokohan mencakup lebih luas atau kesuluruhan dibandingkan dengan pengertian tokoh. Sebab, penokohan mencakup dari segala hal yaitu, siapa tokoh cerita dan bagaimana perwatakan, serta pelukisannya maupun penempatannya pada sebuah cerita. Sedangkan, pengertian tokoh terpacu pada orangnya yaitu pelaku dala cerita mengenai suatu karya sastra. Dalam karya sastra pastinya terdapat amanat yang disampaikan untuk pembaca. Esten (1978:23) mengungkapkan amanat yang baik adalah amanat yang dapat merubah perilaku manusia menjadi lebih baik, mempunyai rasa kemanusiaan dan hati nurani. Menurut Waluyo (dalam Martono,2008:26) amanat adalah pesan yang dibuat oleh pengarang untuk memberi kesan bagi pembaca karya sastra.

Alasan peneliti mengkaji feminisme dalam cerita pendek Air karya Djenar Maesa Ayu dari cerita pendek Kompas Pilihan 2005-2006. Jakarta, 13 Mei 2006 bertujuan untuk 
mendeskrisipkan bentuk-bentuk perjuangan tokoh perempuan untuk melawan penindasan dari laki-laki dan dapat memberikan amanat atau kesan positif yang dapat diambil oleh pembaca karya sastra, inti dari permasalahan yang terjadi yaitu tokoh perempuan ditinggal pergi oleh calon ayah dari si cabang bayi, lantaran si laki-laki tidak ingin mempunyai anak karena merasa usianya masih terlalu muda untuk menjadi seorang ayah. Pada akhirnya tokoh perempuan berjuang hidup sendirian untuk merawat anaknya mulai dari dalam kandungan hingga tumbuh dewasa. Hasil dari penelitian feminisme ini diharapkan mampu menghasilkan manfaat bagi pembaca yang menyukai karya sastra, dan mampu memberikan hasil yang relevan sesuai dengan judulnya yaitu menghasilkan gambaran mengenai perjuangan yang dialami oleh tokoh perempuan.

\section{METODE PENELITIAN}

Metode dalam penelitian ini adalah menggunakan penelitian kualitatif. Moleong (2012:11) mengungkapkan metode deskriptif yaitu data yang berupa gambar, kata-kata, dan bukan angka. Sedangkan bentuk penelitian ini adalah penelitian kualitatif. Penelitian kualitatif yaitu data yang terkumpul dalam bentuk kalimat atau kata-kata karena hasil penelitian ini dipaparkan dalam bentuk kalimat atau kata-kata, serta peneliti berhadapan langsung dengan sastra sebagai sumber data yang akan diteliti.

Sumber data pada peneitian ini adalah cerita pendek Air karya Djenar Maesa Ayu dari cerita pendek Kompas Pilihan 2005-2006. Jakarta, 13 Mei 2006. Syam (2011:12) berpendapat bahwa didalam sebuah penelitian sastra harus terdapat beberapa contoh sumber data yang bersumber dari teks sastra.

Tekhnik analisis data yang dilakukan oleh peneliti adalah menggunakan tekhnik validasi data. Tekhnik validasi data adalah tekhnik membaca berulang-ulang secara intensif, menganalisis data sesuai dengan masalah yang akan diteliti yaitu mengenai perjuangan tokoh perempuan pada salah satu karya Djenar Maesa Ayu dari cerpen Kompas Pilihan 2005-2006 yang berjudul Air.

\section{HASIL DAN PEMBAHASAN}

Penelitian ini menghasilkan bentuk perjuangan yang dialami oleh tokoh perempuan atau tokoh utama dalam cerita pendek Air karya Djenar Maesa Ayu dari cerita pendek Kompas Pilihan 2005-2006. Jakarta, 13 Mei 2006.

Perjungan-perjuangan yang ditemukan dari cerita pendek Air karya Djenar Maesa Ayu yaitu, tokoh perempuan berjuang mempertahankan kandungannya meskipun sang lakilaki tidak menginginkan anak tersebut lahir, serta tega meninggalkan tokoh perempuan dalam keadaan hamil. Kondisi tersebut yang menjadikan tokoh perempuan berjuang dan bekerja keras. Tokoh perempuan menjadi single parent, berjuang demi menghidupi kebutuhan anaknya dan demi kebutuhan sehari-hari. Rela bekerja keras dan tidak mengambil cuti saat bekerja meskipun dengan kondisi yang sudah mulai kontraksi dan kondisi perutnya yang semakin membesar setiap bulannya demi mendapatkan uang untuk mengonsumsi makanan yang sehat dan bergizi, agar anaknya tumbuh dengan baik, sehat, dan pintar. 
Tokoh perempuan menyadari akan arti kerasnya kehidupan, jika dia tidak bekerja dia tidak bisa hidup lebih lama, apalagi demi menghidupi anaknya yang masih bayi. Kebutuhan serta perlengkapan bayi pastinya membutuhkan biaya yang tidak sedikit. Ia memposisikan dirinya sesuai dengan apa yang ia butuhkan, berjuang dan bekerja keras adalah pilihan yang tepat untuk tokoh perempuan yang statusnya single parent. Ia mampu menanggung beban hidupnya, ia bertanggung jawab atas keputusannya yang ia ambil yang mengandung resiko yang berat demi kebutuhan untuk bertahan hidup.

Tokoh perempuan awalnya menjadi seorang SPG, namun tokoh perempuan tidak dapat dipekerjakan lagi karena kondisi penampilan tokoh perempuan yang perutnya semakin membesar. Akhirnya tokoh perempuan pun melahirkan dengan proses alami tanpa proses operasi jadi tidak memperlukan biaya yang besar untuk persalinan. Perjuangan tokoh perempuan tidak berhenti sampai disitu, ia terus berusaha untuk mencukupi kebutuhan anaknya dan kebutuhan sehari-hari dan membayar tagihan-tagihan yang biayanya setiap hari semakin menjulang tinggi, anaknya pun sekarang tumbuh beranjak remaja dan biaya sekolah untuk anaknya pun sungguh mahal.

Tokoh perempuan pun bekerja lebih keras untuk memenuhi kebutuhan yang semakin banyak dan semakin mahal. Tokoh perempuan bekerja menjadi seorang entertain, kondisi ini yang menjadikan tokoh perempuan tidak bisa memperhatikan anaknnya, karena seorang entertain pekerjaan yang dikendalikan oleh sutradara. Meski dalam keadaan bekerja tokoh perempuan selalu memikirkan kondisi anaknya dirumah, memikirkan apakah anaknya sudah makan, memikirkan anaknya sedang apa dirumah, dan memikirkan pergaulan yang dilakukan oleh anaknya dirumah.

Tokoh perempuan menemukan gelas yang berada diatas meja, yang dulunya gelas tersebut berisi air putih jernih sekarang berubah menjadi air kuning yang baunya menyengat. Pergaulan yang diambil anaknya adalah pergaulan yang salah. Hal itu menambah deretan perjuangan tokoh perempuan, meskipun ia tahu bahwa ini semua kesalahan yang ia buat, tidak ada rasa kasih sayang, perhatian, pelukan, serta pengawasan yang baik untuk anaknya. Kondisi tersebut yang membuat tokoh perempuan merasa menyesal kepada anaknya, perjuangan seorang ibu dibalas dengan perbuatan yang tidak baik oleh anaknya.

Dari cerita pendek yang berjudul Air krya Djenar Maesa Ayu, peneliti menemukan beberapa bentuk perjuangan wanita yang mengalami bentuk ketidak adilan yang dilakukan oleh laki-laki yang tidak bertanggung jawab. Wanita di dalam cerita pendek Air karya Djenar Maesa Ayu tersebut memperjuangkan buah hatinya mulai dari masih ada didalam kandungan hingga tumbuh menjadi remaja. Perjuangan wanita sungguh memprihatinkan, tetap bekerja keras meskipun usia kandungannya semakin membesar, tokoh wanita tidak mengambil cuti karena bagi tokoh perempuan kalau tidak punya penghasilan dia akan mati kelaparan. Dari hal-hal tersebut peneliti dapat menyimpulkan bentuk-bentuk perjuangan wanita dalam cerita pendek Air karya Djenar Maesa Ayu.

\section{Bentuk Perjuangan Wanita dalam Cerita Pendek Air karya Djenar Maesa Ayu}

Pada dasarnya wanita adalah sebaik-baiknya kaum yang mulia, karena wanita merupakan kaum spesial yang harus dihormati dan diperlakukan dengan baik. Namun tidak 
untuk zaman sekarang, kaum wanita sungguh dipandang rendah oleh kaum laki-laki, wanita dilecehkan dan harga dirinya di injak-injak oleh kaum lelaki yang tidak mau bertanggung jawab. Bagi kaum laki-laki wanita hanyalah kaum yang lemah dan mudah dirayu, yang dapat memuaskan gairah napsunya dan ditinggakan begitu saja tanpa ada rasa bertanggung jawab. Sungguh keberadaan kaum wanita zaman sekarang sangat memprihatinkan, banyak kaum wanita yang berjuang sendirian untuk memenuhi kebutuhan hidupnya bagi sang buah hati, tanpa mendapatkan pertanggung jawaban dari calon ayah buah hati.

1. Akan kita apakan calon bayi ini? Kita masib terlalu muda," kata ayahnya.

Saya akan menjaganya.

Kutipan diatas menjelaskan bahwa calon ayah dari si cabang bayi tidak menginginkan mempunyai anak karena dengan alasan usianya masih terlalu muda untuk menjadi seorang ayah, akhirnya tokoh perempuan ditinggal pergi oleh calon ayah dari si cabang bayi yang ia kandung, tetapi tokoh perempuan tetap ingin mempertahankan kandungannya dan tidak ingin menggugurkan kandungannya. Dalam kondisi yang tengah hamil sang laki-laki tega meninggalkan tokoh perempuan dan calon bayinya, dengan begitu tokoh perempuan menjadi single parent dan berjuang sendirian menghadapi kenyataan yang pahit, merawat anaknya sendirian tanpa didampingi sang suami, dan berjuang keras demi mendaptkan uang untuk menghidupi kebutuhan sang anak dan kebutuhan sehari-hari.

2. "Rasa waswas setiap kali belum waktunya namun sudab kontraksi. Tidak mengambil cuti, mencari uang demi mengonsumsi makanan bergizi yang konon bisa membuabkan kecanggihan otak maupun fisiknya nanti. Tapi..."

Kutipan diatas menunjukkan bahwa tokoh perempuan sudah mengalami kontraksi, namun tokoh perempuan tidak memperdulikan kondisi tersebut, dalam kondisi seperti itu seharusnya tokoh perempuan mengambil cuti dan istirahat penuh, tetapi tokoh perempuan tidak mengambil cuti meskipun mengalami kontraksi dan perut yang tambah membesar setiap bulannya. Tokoh perempuan tetap berjuang untuk bekerja demi mendapatkan uang untuk mengonsumi makanan yang sehat dan bergizi, karena dengan mengonsumsi makanan yang sehat dan bergizi akan menghasilkan anak yang pintar dan sehat. Tokoh perempuan sungguh ingin merawat anaknya agar nantinya sang anak tumbuh dengan baik dan normal. Sungguh perjuangan yang dialami tokoh perempuan

3. "Tapi tidak mudah memberikan sejuta harapan. Apalagi jika harapan-harapan itu kerap diulang-ulang dan tak pernah mewnjud jadi kenyataan. Karena sudah beribu-ribu kali saya banya pulang membawa sedikit uang. Hanya cukup untuk makan sekadar, membayar listrik, air, telepon, kontrakan, dan sekolah yang semakin hari harganya semakin tinggi menjulang. Dan saya tetap akan pergi. Tetap akan pulang. Ia akan tetap tak membiarkan saya pergi. Tetap menunggu saya pulang."

Kutipan diatas menjelaskan bahwa tokoh perempuan sudah berusaha keras untuk mewujudkan sebuah harapan, tetapi harapan-harapan itu tidak pernah terwujud menjadi kenyataan, tokoh perempuan terus berjuang demi menghidupi anaknya yang sudah beranjak dewasa, beban yang dipikul tokoh perempuan sangat berat. Uang yang terkumpul pun hanya cukup untuk makan sehari-hari, untuk membayar tagihan listrik, air, telepon, kontrakan, dan sekolah pun uangnya sudah tidak cukup karena biaya tagihan tersebut semakin hari harganya semakin menjulang tinggi. Tokoh perempuan tetap memutuskan untuk pergi mencari uang dan bekerja, meskipun ia tahu bahwa anaknya tidak 
menginginkannya pergi, karena sang anak ingin mendapatkan kasih sayang dari seorang ibu, tetapi dengan kondisi yang semakin berat ini memaksakan tokoh perempuan harus bekerja dan tidak bisa menemani anaknya dikontrakan. Potret kehidupan yang dialami oleh tokoh perempuan mencoba pengarang cantumkan dalam karya berbentuk cerita pendek yang sekarang ini karena kondisi tersebut banyak melanda perempuan-perempuan di Indonesia.

4. "Air asin itu mendarat di bibir saya lagi. Lampu-lampu besar seperti makbluk pemeras keringat yang tak berperikemanusiaan. Sudah jam delapan. Baru akan dimulai merekam adegan. Saya harus segera menghayati peran."

Kutipan diatas menjelaskan bahwa tokoh perempuan menjadi seorang entertain dimana kondisi tersebut diatur oleh sutradara, keadaan inilah yang menjadikan tokoh perempuan terpaksa untuk tidak mengabari anaknya, meskipun dalam keadaan bekerja tokoh perempuan selalu memikirkan anaknya yang berada dirumah, memikirkan kondisinya, memikirkan apakah anak tersebut sudah makan, dan memikirkan mengenai pergaulan anaknya dirumah tanpa ada pengawasan dari orang tuanya.

\section{SIMPULAN}

Salah satu karya Djenar Maesa Ayu yang berjudul Air dari Cerpen Kompas Pilihan 20052006. Cerita pendek Air karya Djenar Maesa Ayu menceritakan mengenai perjuangan tokoh perempuan yang ditinggalkan oleh calon ayah dari si cabang bayi, dengan alasan karena lakilaki tersebut usianya masih terlalu muda untuk menjadi seorang ayah, akhirnya laki-laki tersebut dengan tega meninggalkan tokoh perempuan dengan kadaan yang sedang mengandung anaknya. Tokoh perempuan tetap berjuang mempertahankan anaknya yang ada didalam kandungannya, tokoh perempuan berjuang untuk mendapatkan uang agar dapat mengonsumsi makanan yang sehat dan bergizi agar anaknya tumbuh menjadi sehat dan pintar. Gadis kecilnya pun sekarang sudah beranjak remaja, biaya yang dibutuhkan juga semakin banyak. Tokoh perempuan menjadi seorang entertain yang mana pekerjaannya diatur oleh sutradara, tokoh perempuan tidak dapat mengabari gadis cantik itu dirumah dan merasa was-was akan pergaulan yang dipilih oleh anaknya. Dahulu gelas diatas meja berisikan air putih, sekarang berubah menjadi kuning dan berbau menyengat. Kini gadis cantiknya pun mengikuti pergaulan bebas, hal tersebut menambah deretan beban yang dialami oleh tokoh perempuan.

Dari cerita pendek Air karya Djenar Maesa Ayu ini dapat ditarik kesimpulan bahwa tokoh perempuan dapat melawan penindasan laki-laki dengan berjuang untuk memenuhi kebutuhan sehari-hari. Status tokoh perempuan adalah single parent, peran yang dilakukan tokoh perempuan untuk anaknya juga semakin bertambah berat, peran orang tua tidak hanya mencari nafkah untuk anaknya, tetapi juga dapat mengawasi buah hatinya agar tidak terjerumus pada pergaulan bebas. Tokoh perempuan sosok ibu yang bertanggung jawab untuk menghidupi kebutuhan anaknya dan kebutuhan sehari, tetapi dengan bekerja jangan sampai melupakan seorang anak, karena anak membutuhkan rasa kasih sayang, pelukan, serta pengawasan untuk pertumbuhan sang anak agar menjadi anak yang baik dan tidak terjerumus pada pergaulan bebas. Hal itu disadari oleh tokoh perempuan bahwa tokoh perempuan terlalu sibuk bekerja dan tidak mengawasi buah hatinya. 


\section{DAFTAR PUSTAKA}

Aminuddin, 2004. Pengantar Apresiasi Karya Sastra. Bandung: Sinar Baru.

Darussalam, Zulfardi. 2016. "Kajian Feminisme Novel Maimunah Cinta Sang Perawan Karya Charisma W.". Inovasi Pendidikan, Jurnal Ilmiah Pendidikan FKIP Universitas Muhammadiyah Sumatera Barat, Volume 2. No 15, Maret 2016.

Djajanegara, Soenarjati. 2000. Kritik Sastra Feminis: Sebuah Pengantar. Jakarta: PT Gramedia. Fakih. Mansour, 2010. Analisis gender dan Tranformasi Sosial. Yogyakarta: Pustaka Belajar. Junus, umar. 1985. Resepsi Sastra. Jakarta:Gramedia.

Moleong, Lexy J. 2012. Metodologi Penelitian Kualitatif. Bandung: Remaja Rodakarya.

Nurgiyantoro, Burhan. 1995. Teori Pengkajian Fiksi. Yogyakarta: Gajah Mada University Press.

Ratna, Nyoman Kutha. 2009. Teori, Metode, dan Teknik Penelitian Sastra.

Santosa, Puji. 2009. "Perlawanan Bangsa Terjajah Atas Harkat dan Martabat Bangsa: Telaah Postkolonial Atas Tiga Sajak Indonesia Modern”. Atavisme:Jurnal Ilmiah Kajian Sastra, Volume 12, Nomor 2, hlm. 147-156.

Sugihastuti dan Suharto. 2005. Kritik Sastra Feminis: Teori dan Aplikasinya. Yogyakarta: Pustaka Pelajar.

Sumardjo, Jacob dan K.M., Saini. 1994. Apresiasi Kesusasteraan. Jakarta: Gramedia Pustaka Utama.

Syam, Christanto. 2011 Ruang Lingkup Penelitian Sastra. Pontianak: Fakultas Keguruan dan Ilmu Pendidikan.

Uli. Indriyana. 2011. “Citra Perempuan dalam Novel Ratu Kecantikan Harga Sebuah Martabat karya Langit Kresna Hariadi” Skripsi. Pontianak: FKIP UNTAN.

Yogyakarta: Pustaka Pelajar. 